

\section{EDITORIAL ADVISORY BOARD}

Jamal Mонамmеd Анмed, Ministry of Foreign Affairs, Khartoum

Professor G. Balandier, Université de Paris

Sir Kenneth Berrill, Central Policy Review Staff, London

DR S. O. Вгов АKU, Universily of Ibadan

Dr B. T. G. Chidzero, Salisbury, Zimbabue

Professor J. S. Coleman, Unizersity of California, Los Angeles

Professor J. G. St Clair Drake, Stanford University

THOMAS HODGKIN, University of Oxford

ЈонN Holmes, Canadian Institute of International Affairs, Toronto

Helen Kimble, Oxford

Sir arthur Lewis, Princeton University

PROFESSOR C. T. LEYS, Queen's University, Kingston, Ontario

DR AвDOULAYE LY, I.F.A.N., University of Dakar

TAí̇ в Slim, Tunisian Ambassador to Morocco, Rabat

Dr V. G. Solodovnikov, Africa Institute, Academy of Sciences, Moscow

PROFESSOR S. N. VARMA, University of Ife

\section{CONTRIBUTIONS}

Contributions are invited from all over the world, and especially from scholars working in African universities. Articles written in languages other than English will be considered on their merits, and where necessary translation will be arranged. The average length suggested is 4,000 to 6,000 words, with occasional exceptions of up to 10,000 words. Initially, one copy should be submitted, and not the original typescript.

All correspondence and contributions should be addressed to

DR DAVID KIMBLE, Editor of the J.M.A.S.,

Vice-Chancellor of the University of Malawi, P.O. BoX 278, ZOMBA, MALAWI.

Each contributor will receive a copy of the number and 25 offprints of his article free of charge.

Contributors to this Journal express their own opinions, which should not be interpreted as the official view of any institution or organisation with which they may be connected.

\section{SUBSCRIPTIONS}

The Journal of Modern African Studies (ISSN: $0022-278 \mathrm{x}$ ) is published quarterly by Cambridge University Press, The Edinburgh Building. Shaftesbury Road, Cambridge CB2 2 RU, and 32 East 57 th Street, New York, N.Y. 10022.

Single parts cost $\mathcal{L}^{8.50}$ (US $\$_{25.00}$ in the U.S.A. and Canada) plus postage. Four parts form a volume. The subscription price (which includes postage) of volume 19,1981 , is $\$ 27.50$ net (US $\$ 79.50$ in the U.S.A. and Canada) for institutions, $\mathcal{L}_{\mathrm{T}} 4.00$ (US $\$ 39.50$ ) for individuals ordering direct from the publishers and certifying that the Journal is for their personal use.

Orders, which must be accompanied by payment, may be sent to a bookseller or to the publishers (in the U.S.A. and Canada to the New York Office).

Copies of the Journal for subscribers in the U.S.A. and Canada are sent by air to New York to arrive with minimum delay. Second-class postage paid at New York, N.Y., and at additional mailing offices. Postmaster: send address changes in U.S.A. and Canada to Cambridge University Press, 32 East 57 th Street, New York, N.Y. 10022 .

Claims for missing issues will only be considered if made immediately on receipt

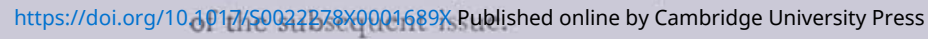




\section{ARTICLES}

\section{ISRAEL AND BLACK AFRICA: A RAPPROCHEMENT?}

Ethan A. Nade lmann, National Science Foundation Fellow in International Relations, Harvard University, Boston

THE BASOTHO NATION-STATE: WHAT LEGACY FOR

THE FUTURE?

Dr Richard F. Weisfelder, Fulbright Lecturer in Politics, University College of Botswana, Gaborone, on leave of absence from the University of Toledo

\section{REVENUE SHARING IN THE NIGERIAN FEDERATION}

Dr LAWRENGE A. RUPLEY, Senior Lecturer in Economics, University of Nairobi

\section{CRISES AND SOCIALISM IN TANZANIA}

Dr Joel Sa moff, International Development Education Committee, School of Education, Stanford University, California

THE REVOLUTIONARY TRANSFORMATION OF

ETHIOPIA'S TWENTIETH-CENTURY BUREAUCRATIC EMPIRE

Dr Edmond J. Keller, Associate Professor of Political Science, Indiana University, Bloomington

\section{REVIEWS}

Economic Imperialism in Theory and Practice: the case of South African gold mining finance, 1886-1914 by ROBERT V. KUBICEK

Dr Roger J. SouthalL, The Norman Paterson School of International Affairs, Carleton University, Ottawa

South Africa into the ig8os edited by Richard E. BisselL and GHESTER

A. GrocKer

Which Way is South Africa Going? by GWEN DOLEN M. CARTER

Dr Timothy M. Shaw, Department of Political Science, Dalhousie University, Nova Scotia

Conflict and Compromise in South Africa edited by R OBERT I. ROTBERG and JоHN BA R R A T T

Suffer the Future: policy choices in Southern Africa by ROBERT I. ROTBERG

Dr S tanley J. Morse, Department of Urban Studies and Planning, Massachusetts Institute of Technology, Cambridge 
Economic Development in Namibia: towards acceptable development strategies for independent Namibia by Wolfgang H. Thomas

Namibia Old and New: traditional and modern leaders in Ovamboland by GE R HA RD

TÖTEMEYER

Christian M. Rogerson, Department of Geography and Environmental Studies, University of the Witwatersrand, Johannesburg

Kaunda on Violence by KenNeTh David Kaunda, edited by Colin M. Morris Mwizenge S. Tемво, Institute for African Studies, University of Zambia, Lusaka

Ujamaa Villages in Tanzania : analysis of a social experiment by MICHAELA VON FREYHOLD

DR JoH N BRIGGs, Department of Geography, University of Glasgow

Malawi: the politics of despair by T. David Wirliams

Dr Stephen Heyneman, Education Department, The World Bank, Washington D.C.

Unity and Struggle: speeches and writings of Amilcar Cabral, texts selected by the

P.A.I.G.C., translated by MichaEL WOLFERs

Ellen VAN De VRUG T, Geographical Institute, State University of Groningen,

The Netherlands

Colonial Rule in Africa: readings from primary sources edited by BRUCE FETTER

African Upheavals Since Independence by Grace STuart I Bingira

Professor Smart A. Ek Po, Department of Political Science, Towson State University, Baltimore

Stability and Instability in Politics: the case of Nigeria and Cameroun by NicH L as

D. Oriaja

Dr SAM. O. Ok a for, Department of Political and Administrative Studies, University of Maiduguri, Bomo State

Nigerian Capitalism by SAYRE P. Schatz

I B Rahim A. KiY A Wa, Department of Economics, Bayero University, Kano

Planning with the Semi-Input-Output Method: with empirical applications to Nigera by ARIE KUYVENHOVEN

Dr MARy Gregory, Department of Political Economy, University of Glasgow

A Krio-English Dictionary compiled by Glifford W. FyLe and ELdRed D. Jones

MICHAEL K'E L LY, Department of Linguistics and Phonetics, University of Leeds

\section{NO LONGER A HIDDEN WAR: REGENT WRITINGS ON THE ERITREAN NATIONALIST STRUGGLE}

Eritrea: the unfinished revolution by RICHARD SHERMAN

Eritrea: Africa's longest war by DAVID POOL

Behind the War in Eritrea edited by Basil Davidson, Lionel Cliffe, and Bereket

Habte Selassie

Conflict and Intervention in the Horn of Africa by Berexet Habte Selassie

Dr John Mark a Is, Faculty of Letters, University of Crete, Rethymnon, Greece 